\title{
Alexithymia, Anxiety and Depression in Patients with Idiopathic Generalized Pruritus
}

\section{İdiyopatik Jeneralize Pruritus Hastalarında Aleksitimi, Anksiyete ve Depresyon}

\author{
Medine Gıynaș Ayhan'르. Zubeyde Tekin Kurku², Ibrahim Eren ${ }^{1}$ \\ ${ }^{1}$ University of Health Sciences, Konya Training and Research Hospital, Department of Psychiatry, Konya \\ ${ }^{2}$ Beyhekim State Hospital, Department of Dermatology, Konya
}

\begin{abstract}
Objectives: Idiopathic generalized pruritus (IGP) is a condition characterized by persistent and generalized pruritus without clinical evidence of inflammation or skin diseases in seemingly healthy skin. Our knowledge about IGP is insufficient as relatively little research has been carried out on this disease. We aimed to assess the prevalence of alexithymia and its association with anxiety and depression in patients with IGP compared with control subjects.

Materials and Methods: The study sample was formed by 35 patients with IGP and 40 control subjects. All the participants were interviewed by using a semi-structured socio-demographic form and all the modules of Structured Clinical Interview for DSM-IV (SCID-I). Toronto Alexithymia Scale (TAS-2o), the Beck Depression Inventory (BDI) and the Beck Anxiety Inventory (BAI) were applied to the participants. Results: Patients with IGP had significantly higher TAS-2o score compared with controls. There was no difference between two groups in terms of BDI and BAI scores. BDI score was positive correlated with TAS-20 and DIF (difficulty in identifying feelings) scores, while BAI score was positive correlated with TAS-20, DIF, DDF (difficulty in describing feelings) and EOT (externally oriented thinking) as well.

Conclusion: The alexithymia prevalence was higher in patients with IGP than that in control subjects, while it was positively correlated with anxiety and depression scores in IGP group. Although larger studies are required, alexithymia and its relationship with depression and anxiety should be taken into consideration while evaluating the patients with IGP.

Keywords: Alexithymia, anxiety, depression, pruritus
\end{abstract}

\section{$\ddot{\mathbf{O z}}$}

Amaç: İdiopatik jeneralize pruritus (IGP), sağlıklı görünen ciltte klinik olarak inflamasyon veya cilt hastalığı olmaksızın persistan ve jeneralize kaşıntı ile karakterize bir durumdur. IGP hakkında nispeten az sayıda araştırma yapıldığından hakkındaki bilgimiz yetersizdir. Bu çalıșmada IGP tanılı hastalarda kontrol grubu ile karşılaştırılarak aleksitiminin yaygınlığını ve anksiyete ve depresyonla ilişkisini değerlendirmeyi amaçladık.

Materyal ve Metot: Çalışmaya 35 IGP tanılı hasta ile 40 sağlıklı kontrol dahil edildi. Tüm katılımcılar DSM-IV'e göre yapılandırılmıș klinik görüșme (SCID-I) ve yarı-yapılandırılmış sosyodemografik form kullanılarak değerlendirildi. Katılımcıların Toronto Aleksitimi Ölçeği (TAS-20), Beck Depresyon Ölçeği (BDI) ve Beck Anksiyete Ölçeği (BAI) doldurmaları sağlandı.

Bulgular: IGP tanılı hastalarda kontrol grubuna göre anlamlı olarak yüksek TAS-2o skoru olduğu bulundu. Gruplar arasında BDI ve BAI skorları yönünden fark yoktu. BDI skoru ile TAS-2o ve DIF (duyguları tanıma zorluğu) arasında pozitif korelasyon gözlendi. BAI skoru ile TAS-20, DIF, DDF (duyguları ifade zorluğu) ve EOT (dışa-dönük düşünce) arasında pozitif korelasyon saptandı.

Sonuç: IGP tanılı hastalarda aleksitiminin prevalansı kontrol grubunda yüksektir ve anksiyete ve depresyonla arasında pozitif korelasyon mevcuttur. Her ne kadar daha kapsamlı çalışmalara ihtiyaç varsa da, IGP tanılı hastalar değerlendirilirken aleksitimi ve aleksitiminin depresyon ve anksiyete ile ilișkisi göz önünde bulundurulmalıdır.

Anahtar kelimeler: Aleksitimi, anksiyete, depresyon, pruritus 
Correspondence / Yazıșma Adresi:

Dr. Medine Giynaș Ayhan

University of Health Sciences, Konya Training and Research Hospital, Department of Psychiatry, Konya

e-mail: drmedineayhan@gmail.com

Date of submission: 19.05.2019

Date of admission: 17.07.2019

\section{Introduction}

Idiopathic generalized pruritus (IGP) is a condition characterized by persistent and generalized pruritus without clinical evidence of inflammation or skin diseases in seemingly healthy skin. Skin diseases (e.g. psoriasis, urticaria), psychiatric (obsessivecompulsive disorders, trichotillomania, body dysmorphic disorders, delusion of parasitosis or factitious disorders) or physical diseases (e.g. renal failure, liver and thyroid function abnormalities, cholestasis, endocrinological and infectious diseases, malignancy), drugs (e.g. anti-hypertensive, anti-bacterial drugs) have to be excluded for its diagnosis. Our knowledge about IGP is sparse as relatively little research has been carried out on this disease. This is possibly because pruritus has multiple possible underlying causes that are often unclear and its diagnosis requires widespread disease exclusion. $^{1-3}$

Alexithymia is a personality trait characterized by limited ability to identify and verbally express emotions, reduced symbolic thinking with poor fantasy and imagination. ${ }^{4}$ Researchers have suggested that alexithymia, manifested with failure to cope with stress and developing fewer close relationships, ${ }^{5}$ can be considered as one of several risk factors for a variety of medical and psychiatric disorder. ${ }^{6-8}$ It is an important featureof psycho-dermatological disorders ${ }^{9}$ and a common personality trait in patients with psychosomatic disorders. ${ }^{4,10}$ Additionally, it is reported that individuals with alexithymia have an impaired ability to build mental representations of emotions, that ordinary somatosensory information is magnified and physical symptoms of emotional arousal are misinterpreted as indicators of physical illness. ${ }^{10}$ Thus, the concept of alexithymia appears to be a key player in the development of psychosomatic disorders.

It is known that psychological factors such as stress, mood and anxiety disorders and personality characteristics are associated with skin disorders. ${ }^{11,12}$ Alexithymia was found to associate with depressive and anxiety symptoms in dermatologic and many other clinical populations. ${ }^{7,8,13-16}$ Psychological factors have been also reported to play an important role in IGP and patients with IGP have a tendency for anxiety and depression. ${ }^{4,17,18}$ Sheehan-Dare et al. ${ }^{17}$ reported a significant difference in depression scores among patients with IGP and compared to general dermatology outpatients; the same authors did not report any difference in anxiety scores.

Pruritus is, alike pain, an unpleasant somatic sensations that share anatomic and physiologic pathways and serve as a protector against harm. $\cdot{ }^{19,20}$ Both have been suggested to reflect interplay with emotional states. ${ }^{21}$ Shibata et al. ${ }^{8}$ found that higher levels of alexithymia are associated with higher risk of having chronic pain in the general population and that individuals with alexithymia have more depression and anxiety symptoms than those without alexithymia. It has also been shown that alexithymic fibromyalgia patients have higher levels of pain. ${ }^{16,22}$ Alexithymia has been associated with a subjective experience of severity of pain, could also be related to 
pruritus. ${ }^{23}$ However, the number of controlled studies to support this view is not sufficient in patients with pruritus and there is no study in the published literature that investigated the contribution of alexithymia in IGP. To our knowledge, this is the first study to evaluate alexithymia, depression and anxiety in patients with IGP.

The aims of the current study were: (a) to examine the prevalence of alexithymia among patients with IGP in comparison to healthy individuals from the general population and (b) to assess the association between depression and anxiety scores and alexithymia, as well as its three subscales, by taking into consideration demographic data of the patients.

\section{Materials and Methods}

This study included 35 consecutive patients diagnosed with IGP who were admitted to the Dermatology Outpatient Clinic, between February 2016 and July 2016. All patients underwent complete physical examination and laboratory investigations based on Kantor's recommendation and previously established guidelines ${ }^{24}$ including complete blood count, glucose, liver, renal and thyroid function tests, age appropriate cancer screening and chest x-ray. Patients with visible skin signs (e.g. eczema, clinical dry skin), a physical or dermatologic cause and pruritic conditions resulting from infections (e.g. hepatitis, human immunodeficiency virus infection) were excluded. The study sample also included a control group consisting of 40 healthy subjects selected from the hospital personnel and their relatives who have no physical disorder according to routine physical examination and laboratory investigations. Controls were matched for sociodemographic characteristics of the patients.

Controls and patients were assessed by using a semi-structured socio-demographic form and all the modules of Structured Clinical Interview for DSM-IV (SCID-I) in the psychiatric outpatient clinic. According to DSM-IV, the participants with significant psychopathology such as major depression, bipolar and psychotic disorder, obsessive compulsive disorder, generalized anxiety disorder or panic disorder were not included the study. All participants were at least elementary school graduates and $\geq 18$ years of age. The other exclusion criteria were mental retardation or cognitive impairment, illiteracy, psychogenic cause of pruritus (e.g. delusions of parasitosis, extensive disfiguring excoriations), current use of psychotropic medication and drug abuse/dependence.

Patients with IGP also completed a semi-structured questionnaire that included duration and severity score of their pruritus on a 4-point scale. The scale used in the assessment of the severity of pruritus was consisted of four options and the scores for each option was ranged from "o" to " 3 " respectively. Pruritus scores were determined in the following way: No pruritus (o point); Mild - occasionally mild pruritus (1 point); Moderate - not awaken from night sleep, intermittent or continuous pruritus (2 point); Severe - awaken from night sleep, annoying pruritus (3 point). Patients were recruited if their symptoms were present for at least 6 months and if they rated 2 or 3 points according to severity score.

Three patients with major depression, 5 patients using psychotropic medication and 6 patients rated 1 point according to pruritus severity score were not included in the study. The Toronto Alexithymia Scale-2o (TAS-20), Beck Depression Inventory (BDI) and Beck Anxiety Inventory (BAI) were applied to all participants to compare the 
groups regarding with the scores of alexithymia, anxiety and depressive symptoms along with the collection of demographic and clinical data.

The study was approved by the local Ethics Committee and written informed consent was obtained from all participants.

\section{Measurements}

Toronto Alexithymia Scale (TAS-20): TAS-20 is a 20-item self-report scale on a 5-point Likert scale, ranging from 1 (strongly disagree) to 5 (strongly agree), with five items negatively keyed. The scale consists of a three-factor structure congruent with the alexithymia construct: difficulty in identifying feelings (DIF), difficulty in describing feelings (DDF) and externally oriented thinking (EOT), respectively. The total score ranges from 20 to 100 . A total score above 61 indicates alexithymia; a score between 52 and 60 suggests intermediate/borderline alexithymia and a score lower than 51 indicate absence of alexithymia ${ }^{25}$ Validity and reliability studies have been performed for the Turkish population. ${ }^{26}$

Beck Depression Inventory (BDI): The BDI consists of 21 questions, each with a score between o and 3. The minimum total score is o and the maximum total score is 63 . Scores between o and 13 are scored as "minimal" depression, scores between 14 and 19 are scored as "mild" depression, scores between 20 and 28 are scored as "moderate" depression and scores 29 and above are considered to be consistent with "severe" depression. Higher scores indicate greater depressive symptoms. ${ }^{27}$ Validity and reliability studies have been performed for the Turkish population. ${ }^{28}$

Beck Anxiety Inventory (BAI):The BAI also consists of 21 questions, each with a score between $\mathrm{o}$ and 3. Total scores between $\mathrm{o}$ and 21 are interpreted as low anxiety, total scores between 22 and 35 are consistent with moderate anxiety, and total scores greater than or equal to 36 are interpreted as evidence of severe anxiety. ${ }^{29}$ Higher scores represent a higher intensity level of anxiousness. Validity and reliability studies have been performed for the Turkish population. ${ }^{30}$

\section{Statistical analysis}

Data analysis was conducted using SPSS (version 15.0). Normality was assessed by Kolmogorov-Smirnov's test. Categorical data were compared using the chi-square test and continuous data using Mann-Whitney U test. Definitive statistics were expressed as mean \pm standard deviation for continuously measured variables, and a case number and (\%) for nominal variables. Correlations were measured by Spearman's correlation coefficient between TAS-20, its subscales and age, education level, BDI and BAI. Statistical significance was accepted as $\mathrm{p}<0.05$.

\section{Results}

The study included 75 participants, 35 in the IGP group and 40 in the control group. All participants were between 19-6o years of age and the mean age of the sample was $36.47 \pm 11.74$ years. Both the IGP and control groups consisted predominantly of females ( $77.14 \%$ and $75.0 \%$ respectively). There was no significant difference between the groups with regard to age, gender, marital and employment status, educational level and number of children. The socio-demographic characteristics of the patient and control groups are shown in Table 1. 
Table 1. Sociodemographic Characteristics IGP and Control Groups

\begin{tabular}{|l|c|c|c|}
\hline & $\begin{array}{c}\text { IGP Group } \\
(\mathbf{n = 3 5})\end{array}$ & $\begin{array}{c}\text { Control Group } \\
(\mathbf{n = 4 0})\end{array}$ & $\mathbf{P}$ \\
\hline Mean Age (Mean \pm SD) & $36.60 \pm 12.75$ & $36.33 \pm 10.75$ & $0.624^{* *}$ \\
\hline $\begin{array}{l}\text { Educational level } \\
\text { (years)(Mean } \pm \text { SD) }\end{array}$ & $9.36 \pm 4.64$ & $10.23 \pm 4.86$ & $0.585^{* *}$ \\
\hline $\begin{array}{l}\text { Gender (n, \%) } \\
\text { Female } \\
\text { Male }\end{array}$ & $\begin{array}{c}27(77.14 \%) \\
8(22.86 \%)\end{array}$ & $\begin{array}{l}30(75.0 \%) \\
10(25.0 \%)\end{array}$ & $0.325^{*}$ \\
\hline
\end{tabular}

*Ki-square test; ** Mann-Whitney U Test, $\mathrm{p}<0.05$ significant, SD: Standard deviation

Based on the TAS-2o standards, the prevalence of alexithymia in patients with IGP was as follows: $11(31.43 \%)$ patients were classified as alexithymic, $14(40.0 \%)$ as borderline and $10(28.57 \%)$ as non-alexithymic. There were significant differences between patient and control groups regarding the presence of alexithymia $(\mathrm{p}=\mathrm{0.002})$, but no difference in terms of the BDI score at a cut off $\geq 17(\mathrm{p}=0.184)$. According to TAS-20 and BDI scores, no statistically significant differences were found on the basis of gender in the IGP group for the presence of alexithymia $(\mathrm{p}=0.160)$ and depression $(\mathrm{p}=\mathbf{0 . 2 2 2})$.

The mean alexithymia score according to TAS-20 was $55.03 \pm 11.67$ in the IGP group, and $45.64 \pm 8.03$ in the control group $(\mathrm{p}=0.006)$. The mean anxiety (BAI) and depression (BDI) scores of patients with IGP were $12.16 \pm 8.58$ and1o.83 \pm 9.12 , respectively. Significant differences were found between patients with IGP and control subjects in TAS-20 ( $\mathrm{p}=0.006)$, DDF (difficulty in describing feelings) $(\mathrm{p}=0.003)$ and EOT (externally oriented thinking) $(\mathrm{p}=\mathrm{o.007})$ scores. There were no significant differences in the DIF (difficulty in identifying feelings), BDI and BAI scores between patients with IGP and control subjects (Table 2).

Table 2. Alexithymia, Depression and Anxiety Scores in IGP and Control Groups

\begin{tabular}{|l|c|c|c|}
\hline & IGP Group $(\mathbf{n}=35)$ & Control Group $(\mathbf{n}=\mathbf{4 0})$ & P \\
\hline TAS-20 & $55.03 \pm 11.67$ & $45.64 \pm 8.03$ & $\mathbf{0 . 0 0 6}^{*}$ \\
\hline DIF & $16.40 \pm 7.38$ & $14.11 \pm 5.16$ & 0.312 \\
\hline DDF & $14.67 \pm 3.18$ & $12.27 \pm 3.13$ & $\mathbf{0 . 0 0 3}^{*}$ \\
\hline EOT & $22.87 \pm 5.03$ & $19.64 \pm 3.67$ & $\mathbf{0 . 0 0 7}^{*}$ \\
\hline BDI & $12.16 \pm 8.58$ & $11.11 \pm 8.73$ & 0.569 \\
\hline BAI & $10.83 \pm 9.12$ & $7.27 \pm 6.32$ & 0.092 \\
\hline
\end{tabular}

Mann Whitney U Test, DIF: difficulty in identifying feelings, DDF: difficulty in describing feelings, EOT: externally oriented thinking, TAS-20: Toronto Alexithymia Scale-20, BDI: Beck Depression Inventory, BAI: Beck Anxiety Inventory, * $\mathrm{p}<0.05$ significant

No correlation could be identified between the TAS-20 and age. Educational level was negatively correlated with TAS-2o and DIF scores, whereas was not correlated with DDF and EOT. BDI was positively correlated with TAS-20 and DIF scores. There was significantly positive correlation between BAI and TAS-20 score. The correlations between TAS-20, its subscales and BDI, BAI, age and education level in IGP group are shown in Table 3. 
Table 3. Correlations between TAS-20, its subscales and BDI, BAI, age and educational level in IGP group

\begin{tabular}{|l|c|c|c|c|}
\hline & Age(r) & $\begin{array}{c}\text { Educational } \\
\text { level(r) }\end{array}$ & BDI(r) & BAI(r) \\
\hline TAS-20 & $0.223^{\mathrm{a}}$ & $-0.582^{* *}$ & $0.428^{*}$ & $0.697^{* *}$ \\
\hline DIF & $0.199^{\mathrm{a}}$ & $-0.446^{*}$ & $0.363^{*}$ & $0.577^{* *}$ \\
\hline DDF & $0.002^{\mathrm{a}}$ & $-0.342^{\mathrm{a}}$ & $0.355^{\mathrm{a}}$ & $0.496^{* *}$ \\
\hline EOT & $0.262^{\mathrm{a}}$ & $-0.324^{\mathrm{a}}$ & $0.304^{\mathrm{a}}$ & $0.481^{* *}$ \\
\hline
\end{tabular}

$\mathrm{r}=$ Spearman's correlation coefficient in the IGP group. DIF: difficulty in identifying feelings, DDF: difficulty in describing feelings, EOT: externally oriented thinking, TAS-20: Toronto Alexithymia Scale20, BDI: Beck Depression Inventory, BAI: Beck Anxiety Inventory, ${ }^{*} \mathrm{p}<0.05,{ }^{* *} \mathrm{p}<0.01,{ }^{a}$ non-significant

\section{Discussion}

In this study, we found a significantly higher prevalence of alexithymia in IGP patients compared to healthy subjects. No significant differences were found in depression and anxiety scores between the patient and control groups; however, the scores were overall higher in the patient group. A negative correlation was identified between education level and alexithymia and its subscale DIF; depression score of patients was positively correlated with alexithymia and DIF scores while anxiety scores of patients were positively correlated with alexithymia and its three subscales (DIF, DDF and EOT).

The majority of studies reveal a higher prevalence of alexithymia as a personality trait in male rather than female individuals in the general population. ${ }^{9}$ However, in our study, there were no significant differences in the TAS score or in its subscales in IGP patients on the basis of gender. This may be because the sample used in the current study was predominantly female. Our results also indicate that the alexithymia score in patients with IGP was not correlated with age, consistent with the results of other studies. ${ }^{31}$

It is known that chronic skin diseases can be triggered or exacerbated by psychological distress $^{12}$ as well as mood and anxiety disorders, and personality characteristics. ${ }^{11}$ Alexithymic individuals in general fail to cope with stress, have difficulties in describing their feelings, inability to forge close relationships, poor social skills, and are under the risk of developing skin diseases. ${ }^{5}$ Thus, it has been suggested that alexithymia should be evaluated in the context of depression and anxiety to understand the role of emotional dysregulation as a triggering factor in skin diseases. ${ }^{6,11,17}$ It is also thought that idiopathic pruritus may be affected by psychological factors and may have psychiatric co-morbidity. ${ }^{17,32}$ It has been reported that localized idiopathic pruritus, particularly in the anogenital region, could be related to anxiety and depression.33However, the number of controlled trials is insufficient to establish these relationships.

AT-J Goon et al.'reported that anxiety and depression, which are common in chronic pruritus, might be possible predisposing factors for IGP. Through psychological examination of the patients, Sheehan-Dare et al. ${ }^{17}$ demonstrated an association between IGP and depression and anxiety. These authors reported that the mean BDI 
and trait anxiety scores were higher for patients with pruritus than controls but the difference in scores was not statistically significant. Identification of depression or anxiety was recommended as it might provide an opportunity to reduce morbidity in patients with pruritus. ${ }^{17}$ Consistent with these findings, in the current study we did not obtain a significant difference in total depression and anxiety scores between the IGP and control groups; however, the BDI score was higher than the cut-off score of 17 in $36.7 \%$ of the IGP patients and $23.3 \%$ of the controls.

Heisig et al. ${ }^{34}$ reported no significant difference in the total score of alexithymia between patients with and without uremic pruritus (UP). However, these authors reported that the ability to fantasize (not included in TAS-20) and daydream was higher in patients with UP compared with those without pruritus. These authors have interpreted this as a mechanism of coping with pruritus by aiming to divert patient's attention away from the itching. The authors also recommended investigating whether pruritus significantly affected alexithymia in other patients, especially in those with pruritus of unknown origin. In the current study, we have evaluated the literature for alexithymia in other skin diseases, since no published studies have investigated alexithymia in IGP. The prevalence of alexithymia in IGP (31.4\%) was similar to alopecia areata $(42.0 \%)$ and psoriasis $(32.4-34.8 \%)$ and was significantly higher than the control group $(6.7 \%)$ and the general population $(10-13 \%) .13,15,31,35 \mathrm{On}$ the other hand, the pain, uses similar pathophysiologic mechanisms like pruritus, was also investigated for alexithymia and alexithymia was found to be significantly higher in patients with chronic pain. ${ }^{16,22}$ These findings suggest that alexithymia may be a predisposing factor for IGP, similar to other psychosomatic skin diseases and chronic pain.

Several studies have shown a positive correlation between the symptoms of alexithymia, anxiety and depression and it is suggested that patients with depression and anxiety are prone to developing alexithymic features. ${ }^{36-38}$ Tesio et al. ${ }^{22}$ also reported higher alexithymia prevalence and correlation between alexithymia scores and depression and anxiety scores in fibromyalgia patients with chronic pain. Similar to these findings, we found positive correlations between alexithymia and its three subscales (DIF, DDF and EOT) and anxiety score, as well as between alexithymia and DIF and depression score. This suggests that psychological status may underlie a patient's difficulties to identify and describe emotions as previously reported. ${ }^{36-}$ ${ }^{38}$ However, it is still unknown if pruritus is a sign of alexithymia or pruritus develops as a response to alexithymia in IGP.

In line with findings reported previously,37a moderate level of negative correlation between years of education and alexithymia score in the IGP group is another finding of our study. Therefore, we think psychotherapy for IGP patients may be helpful. Although there are no randomized controlled studies about the efficiency of psychotherapeutic treatment in psychosomatic skin diseases, modified psychotherapeutic approaches have been defined for alexithymic patients. ${ }^{39}$ Allegranti et al. ${ }^{14}$ suggested integrated psychotherapy for dermatologic alexithymic patients, in particular with the aim of helping to recognize their inner feelings and to use them as signals of emotional stress. Thus, we think that alexithymic patients with IGP may benefit from learning to express and control their emotions in a proper way with an empathic and supportive approach. 
Our study has some limitations. First of all, our sample size is small and is composed of patients presenting to the dermatology clinic, who may not represent all patients with idiopathic generalized pruritus. Thus, studies covering the general population need to be conducted. Another limitation is that this research cannot answer whether alexithymia, depression and anxiety lead to IGP, or contrarily, IGP leads to alexithymia, depression and anxiety because of the cross-sectional design of our study.

Despite some limitations, the results of the current study suggest that alexithymia has a higher prevalence in patients with IGP than controls. Additionally, alexithymia in patients with IGP seems to be associated with depression and anxiety. Patients frequently do not report their psychological symptoms spontaneously to their health caregivers. For this reason, all patients with IGP should be examined for alexithymia, depressive and anxiety symptoms regardless of the absence of significant psychological complaints. In addition, we think that further prospective studies with larger sample sizes that investigate alexithymia, depression and anxiety in individuals with IGP would address this issue.

The abstract of this study was presented as poster presentation at the " $52^{\text {nd }}$ National Psychiatry Congress, Antalya, Turkey, November 16-20, 2016".

\section{Competing interests}

The authors declare that they have no conflict of interest.

\section{Financial Disclosure}

The financial support for this study was provided by the investigators themselves."

\section{Ethical approval}

Ethical approval was obtained from the hospital administration to use the patients' data.

\section{References}

1. T-J Goon A, Yosipovitch G, Chan YH, Goh CL. Clinical characteristics of generalized idiopathic pruritus in patients from a tertiary referral center in Singapore. Int J Dermatol 2007;46:1023-6.

2. Afifi Y, Aubin F, Puzenat E, et al. Pruritus sine materia: a prospective study of 95 patients. Rev Med Interne 2004;25:490-3.

3. Zirwas MJ, Seraly MP. Pruritus of unknown origin: a retrospective study. J Am Acad Dermatol 2001;45:892-6.

4. Sifneos PE. The prevalence of 'alexithymic' characteristics in psychosomatic patients. PsychotherPsychosom 1973;22:255-62.

5. Picardi A, Porcelli P, Mazzotti E et al. Alexithymia and global psychosocial functioning: a study on patients with skin disease. J Psychosom Res. 2007;62:223-9.

6. Willemsen R, Roseeuw D, Vanderlinden J. Alexithymia and dermatology: the state of art. Int J Dermatol 2008;47:903-10.

7. Ghiggia A, Romeo A, Tesio V et al. Alexithymia and depression in patients with fibromyalgia: When the whole is greater than the sum of its parts. Psychiatr Res 2017;255:195-7.

8. Shibata M, Ninomiya T, Jensen MP et al. Alexithymia is associated with greater risk of chronic pain and negative affect and with lower life satisfaction in a general population: the Hisayama Study. PloS one 2014;9:e90984.

9. Poot F, Sampogna F, Onnis L. Basic knowledge in psychodermatology.J EurAcadDermatolVenereol 2007;21:227-34. 
10. Taylor GJ, Bagby RM, Parker JDA. Disorders of affect regulation: alexithymia in medical and psychiatric illness. Cambridge: Cambridge Univ. Press, 1997:67-137.

11. Gupta MA, Gupta AK. Psychiatric and psychological co-morbidity in patients with dermatologic disorders: epidemiology and management. Am J Clin Dermatol 2003;4:833-42.

12. Picardi A, Abeni D. Stressful life events and skin diseases: disentangling evidence from myth. Psychother Psychosom 2001;70:118-36.

13. Giovannelli L, Barbasio C, Burroni AG, Fassino M, Parodi A, Granieri A. Alexithymia, dissociation, and trauma in patients with chronic skin conditions. Giornaleitaliano di dermatologia e venereologia: organoufficiale, Societaitaliana di dermatologia e sifilografia 2016;151:347-52.

14. Allegranti I, Gon T, Magaton-Rizzi G, et al. Prevalence of alexithymic characteristics in psoriatic patients. Acta Derm Venereol Suppl (Stockh) 1994;186:146-7.

15. Sellami R, Masmoudi J, Ouali U et al. The relationship between alopecia areata and alexithymia, anxiety and depression: a case-control study. Indian J Dermatol 2014;59:421.

16. DiTella M, Ghiggia A, Tesio V et al. Painexperience in FibromyalgiaSyndrome: The role of alexithymiaandpsychologicaldistress. JAffectDisord. 2017;208:87-93.

17. Sheehan-Dare RA, Henderson MJ, Cotterill JA. Anxiety and depression in patients with chronic urticaria and generalized pruritus. Br J Dermatol 1990;123:769-74.

18. Yosipovitch G, David M. The diagnostic and therapeutic approach to idiopathic generalized pruritus. Int J Dermatol 1999;38:881-7.

19. Baron R, Schwarz K, Kleinert A, Schattschneider J, Wasner G. Histamine-induced itch converts into pain in neuropathic hyperalgesia. Neuroreport 2001;12:3475-8

20. Yosipovitch G, Carstens E, McGlone F. Chronic itch and chronic pain: analogous mechanisms. Pain 2007:131:4-7.

21. Psouni EE. On psychological factors affecting reports on itch perception. In: Yosipovitch G, Greaves MW, Fleischer AB, McGlone F, editors. Itch basic mechanisms and therapy. New York: Marcel Dekker Inc., 2004:351-66.

22. Tesio V, Di Tella M, Ghiggia A et al. Alexithymia and Depression Affect Quality of Life in Patients with Chronic Pain: A Study on 205 Patients With Fibromyalgia. Front Psychol 2018;9:442.

23. Lumley MA, Smith JA, Longo DJ. The relationship of alexithymia to pain severity and impairment among patients with chronic myofascial pain: comparisons with self-efficacy, catastrophizing, and depression. J Psychosom Res. 2002;53:823-30.

24. Kantor GR, Bernhard JD. Investigation of the pruritic patient in daily practice. SeminDermatol 1995;14:290-6.

25. Bagby RM, arker JD, Taylor GJ.The twenty-item Toronto Alexithymia Scale-I. Item selection and cross-validation of the factor structure. J Psychosom Res 1994;38:23-32.

26. Güleç H, Köse S, Güleç MY et al. Reliability and Factorial Validity of the Turkish Version of the 2o-Item Toronto Alexithymia Scale (TAS-20). Klinik Psikofarmakoloji Bülteni 2009;19:213-9.

27. Beck AT, Ward CH, Mendelson M, Mock J, Erbaugh J. An inventory for measuring depression. Arch Gen Psychiatry 1961;4:561-71.

28. Hisli N. A study on the validity of Beck Depression Inventory. Turk J Psycho 1988;6:118-22.

29. Beck AT, Epstein N, Brown G et al. An inventory for measuring clinical anxiety: Psychometric properties. J Consult Clin Psychol 1988;56:893-7.

3o. Ulusoy M, Sahin NH, Erkmen H. Turkish version of the Beck Anxiety Inventory: Psychometric properties. J Cognitive Psychother 1998;12:163-72.

31. Korkoliakou P, Christodoulou C, Kouris A et al. Alexithymia, anxiety and depression in patients with psoriasis: a case control study. Ann Gen Psychiatry 2014;13:38.

32. Yosipovitch G, Samuel LS: Neuropathic and psychogenic itch. Dermatol Ther 2008;21:32-42

33. Laurent A, Boucharlat J, Bosson JL, Derry A, Imbert R. Psychological assessment of patients with idiopathic pruritus ani. Psychother Psychosom 1997;66:163-6.

34. Heisig M, Reich A, Szepietowski JC. Alexithymia in Uraemic Pruritus. Acta Derm Venereol 2016;96:699-700.

35. Salminken JK, Saarijärvi S, Aärelä E, Toikka T, Kauhanen J. Prevalence of alexithymia and its association with sociodemographic variables in the general population of Finland.J Psychosom Res 1999;46:75-82. 
36. Honkalampi K, Hintikka J, Tanskanen A, Lehtonen J, Viinamäki H. Depression is strongly associated with alexithymia in the general population. J Psychosom Res 2000;48:99-104.

37. Honkalampi K, Saarinen P, Hintikka J, Virtanen V, Viinamäki H. Factors associated with alexithymia in patients suffering from depression. Psychother Psychosom 1999;68:270-5.

38. Fortune DG, Richards HL, Griffiths CE, Main CJ. Psychological stress, distress and disability in patients with psoriasis: consensus and variation in the contribution of illness perceptions, coping and alexithymia. Br J Clin Psychol 2002;41:157-74.

39. Arnold LM, Auchenbach MB, McElroy SL. Psychogenic Excoriation. Clinical Features, proposed diagnostic criteria, epidemiology and approaches to treatment. CNS Drugs 2001;15:351-9. 